\title{
AS CONSEQUÊNCIAS dA ATUAÇÃo do MAGISTRAdo SÉRGIO MORO NO CASO DA DIVULGAÇÃO DAS INTERCEPTAÇÕES TELEFÔNICAS EM MARÇO
} DE 2016

Fernando Vechi

Bacharel em Direito pela Universidade do Extremo Sul Catarinense (UNESC). Mestre e doutorando em Ciências Criminais pela Pontifícia Universidade Católica do Rio Grande do Sul - PUCRS (Bolsista CAPES). Membro e pesquisador do grupo de estudos Criminologia, Cultura Punitiva e Crítica Filosófica (PUCRS). Membro e pesquisador do Grupo Andradiano de Criminologia Critica (UNESC).

\begin{abstract}
RESUMO
Este trabalho visa demonstrar a problemática e as consequências da visibilidade dada a um magistrado tomando como estudo de caso a publicidade das interceptações telefônicas em duas edições do Jornal Nacional em março de 2016. Diante de uma profissão que exige imparcialidade, dedicação, prudência, celeridade e discernimento, quais as consequências político-jurídicas daquele que se encontra na posição de julgador e para as partes das decisões proferidas por tal agente. A análise será desenvolvida a partir de uma investigação envolvendo Luiz Inácio Lula da Silva e que afeta a figura da ex-presidente Dilma Rousseff. Trabalha-se com pesquisa teórico-bibliográfica, utilizando para tanto o marco teórico proporcionado pela sociologia $\mathrm{e}$ criminologia. A atuação do magistrado violou direitos e princípios constitucionais, causando uma grande mancha na imagem dos políticos envolvidos.
\end{abstract}

Palavras-chave: Judiciário. Magistrado. Interceptações telefônicas. Punitivismo.

\section{INTRODUÇÃO}

A figura central da Operação Lava Jato foi o magistrado Sérgio Fernando Moro, na época titular da $13^{a}$ Vara Federal de Curitiba. Sua atuação ganhou destaque quando a Operação Lava Jato, ao chegar na 24. ${ }^{\text {a }}$ fase cunhada Aletheia, envolveu figuras políticas de grande 
renome. O ex-presidente Luiz Inácio Lula da Silva passou a ser investigado no ano de 2016 pelos crimes de corrupção passiva, ativa e lavagem de dinheiro. A Operação fez soma a deslegitimação da política e dos políticos envolvidos, expondo todos os casos de maior repercussão na mídia televisiva ou eletrônica. Estes se transformaram em escândalos políticos ${ }^{1}$, os quais podem ser uma grande arma e estratégia poderosa para manchar a reputação de um político, consagrando a oposição.

O magistrado se tornou verdadeira celebridade nacional com direito a mesma comparação a Joaquim Barbosa na época das investigações do "Mensalão"². O juiz atuava na operação Lava Jato desde março de 2014. Em seu passado, trabalhou com outras operações que também envolviam agentes políticos e grandes empresários, como no caso denominado Mensalão e na Operação Farol da Colina (MINISTÉRIO PÚBLICO FEDERAL, 2018). Há 10 anos este magistrado se encontra envolvido com o "combate a corrupção".

A problemática se insere justamente em sua posição e atuação na exposição dos grampos telefônicos que envolvia o ex-presidente Lula e Dilma Rousseff. Toda a conversa foi colocada em duas edições seguidas do Jornal Nacional tratando apenas sobre este caso, num jornal que alcança milhões de telespectadores e, a partir disso, traz à tona, a problemática das consequências do ponto de vista da expansão de um poder punitivo. Conforme o Juiz da Corte Interamericana de Direitos Humanos, Eugenio Raúl Zaffaroni, a punição é uma ação que leva em conta qualidades pessoais, "posto que o sistema penal, dada sua seletividade, parece indicar mais qualidades pessoais do que ações, porque a ação filtradora o leva a funcionar desta maneira" (ZAFFARONI; PIERANGELLI, 2011, p. 70).

Como alerta Zaffaroni (2013) há um crescente advento do autoritarismo ${ }^{3}$ e do poder punitivo e admitir um tratamento diferenciado, como este em objeto, divulgando conversas

\footnotetext{
${ }^{1} \mathrm{O}$ conceito de escândalo político provém do sociólogo John Brookshire Thompson (2001). Na obra El escándalo político Poder y visibilidad en la era de los medios de comunicación, o conceito de escândalo diz respeito a violação de normas ou valores que geram uma desaprovação publicamente mediada. $\mathrm{O}$ autor resgata nos gregos antigos a origem etimológica do termo, onde escândalo representava uma armadilha, uma espécie de obstáculo ou deslize moral. A gênese dessa palavra se aproxima do significado daquela que empregamos atualmente. Os escândalos já existiam antes, mas um fator importante para que tomasse as proporções e consequências que alcançaram na contemporaneidade foi a visibilidade mediada. A partir disso, os escândalos se desenvolveram nas sociedades modernas e foram ampliados globalmente. Entretanto, cabe ponderar que cada cultura lida de uma forma particular e específica com uma ação moral reprovável.

2 "Mensalão" se refere à Ação Penal 470, que envolvia a compra de votos envolvendo a figura de políticos renomados.

${ }^{3}$ Para Marilena Chaui (2013, p. 132) o autoritarismo não é um fenômeno político que atinge apenas o Estado, mas sim, que reveste toda a sociedade através de características e traços autoritários: divisões sociais naturalizadas em desigualdades; legislação como privilégio de uma classe; repressão das camadas populares; indistinção entre o público e o privado - "Do ponto de vista dos direitos, há um encolhimento do espaço público; do ponto de vista dos interesses econômicos, um alargamento do espaço privado" (CHAUI, 2013, p. 133); práticas ideológicas de nacionalismo militante com caráter unificador do povo em uma identidade nacional com a exclusão da diferença e da pluralidade.
} 
sigilosas entre presidenta e ex-presidente em rede televisiva nacional, coloca em questão a própria dinâmica de limitações à liberdade de toda a população, dado que se pode fazer isso com uma presidenta, autoridade máxima do executivo, o que será da privacidade e intimidade da população quando se faz necessário a resolução da "[...] eficácia humanitária do poder punitivo que declara perseguir apenas a neutralização do risco da emergência do momento" (ZAFFARONI, 2007, p. 118).

Ainda que, posteriormente, a divulgação das conversas tenha sido considerada ilegal pelo Ministro Teori Zavascki, esse fato não remediou as consequências políticas da postura do Magistrado e da divulgação na mídia em relação aos agentes políticos envolvidos.

\section{OS LIMITES DO JUIZ PENAL EM UM ESTADO DEMOCRÁTICO DE DIREITO ${ }^{4}$}

O magistrado é um funcionário público investido com o poder-dever de dizer o direito, isto é, de exercer a jurisdição sobre determinado território. Ele integra o sistema de justiça brasileiro e possui um papel fundamental a respeito de sua responsabilidade perante a população que o cerca. Suas decisões e seus comandos interferirão profundamente sobre vidas, atingindo a sociedade como um todo. Dessa forma, é uma função que exige acima de qualquer outra, imparcialidade, celeridade, prudência e discernimento frente aos milhares de conflitos que acontecem diariamente.

Especificamente o magistrado criminal é alguém que está lidando diretamente com vidas humanas e sentenciando pessoas a serem trancafiadas (ou não) em um sistema prisional ${ }^{5}$ que se encontra no momento da escrita deste artigo na quarta posição mundial do maior número de pessoas encarceradas (BRASIL, 2016a, p. 8).

Segundo o modelo adotado no Brasil, o magistrado só pode atuar quando provocado ${ }^{6}$. Ele não pode dar início a um processo judicial e, tampouco, decidir uma questão qualquer sem

\footnotetext{
${ }^{4}$ No Estado Democrático de Direito há a necessidade de se promover o que se denomina de justiça social, pensando principalmente num projeto-político democrático, não apenas na aplicação da lei, mas caminhando por meio de uma justiça material que vise à resolução de conflitos plurais. A verdadeira mudança se encontra no que este Estado tem de democrático na promoção dos direitos fundamentais. O poder do Estado deve se organizar em uma ordem que legitime o povo, onde valores e princípios de igualdade, nos dizeres de Canotilho (1999), sejam enraizados num Estado de direito - limitando o poder político.

${ }^{5}$ Concorda-se com a crítica de Alessandro Baratta (2002) ao falar das condições do cárcere e sentenciar a frase de que "a melhor prisão é, sem dúvida, a que não existe" ou "a melhor prisão é a que menos prisão for", uma vez que a vida no cárcere é encarada como violência institucional e não conduz a qualquer forma de reintegração social ou teorias "re".

${ }^{6} \mathrm{O}$ princípio da inércia do magistrado é designado no fato de que o Estado só atua quando for provocado pelas partes que estão no conflito. Isto é, o magistrado não pode agir por vontade própria, ou seja, ne procedat iudex ex
} 
ser impelido. Daí a importância de se ter um judiciário que é capaz de conter abusos à Constituição e ao Estado Democrático de Direito, sem que, contudo, usurpe atribuições de outros poderes e que esteja acima do bem e do mal (como superego ${ }^{7}$ ).

Assim, a crítica se encontra justamente num ativismo punitivo por parte dos magistrados na área criminal em realizar um verdadeiro combate à criminalidade. Um ativismo que coloca o magistrado em uma posição de ator político criminal e pelo qual "os juízes, agora, só são visíveis de vermelho" (AMARAL; ROSA, 2015, p. 67). Augusto Jobim do Amaral (2015, p. 77), em sua parte do livro Cultura da punição: a ostentação do horror, explica que o magistrado que atua na vara criminal está cercado de pressão e exposição midiática (punitiva) e deve manejar, ainda assim, como contrapoder de tutela de minorias, porque deve evitar a posição de um santo guerreiro:

[...] um juiz inscrito numa cruzada contra o crime não se encontra mais na posição de um terceiro imparcial; preso a um papel de "santo guerreiro" [saint belliqueux] dedicado a uma missão sagrada corre o risco de quebrar os princípios que regem a sua própria função (SALAS, 2010, p. 234 apud AMARAL; ROSA, 2015, p. 77).

Importante salientar que através desta posição de combate, o magistrado perde a dimensão das consequências de sua decisão e separa a sociedade de forma maniqueísta. Em defesa da sociedade, o ativismo punitivo se sobressai. A perda da sensibilidade de juízes está ligada às questões humanas que são tratadas de formas burocráticas e padronizadas no dia-adia da vara criminal. Além disso, as metas impostas pelo Tribunal a serem atingidas para promoção se dão através das soluções fast-foods ${ }^{8}$ que vão pouco a pouco minando a posição do magistrado dentro de um Estado Democrático de Direito.

Essa objetificação de vidas se faz presente em um sistema inquisitório, onde o réu é um mero objeto na mão do juiz que detém todas as funções em sua mão, seja de acusador, seja de julgador. Por isso a iniciativa probatória deve estar presente nas mãos das partes. Uma das principais características do modelo dispositivo no sistema acusatório é a posição do magistrado enquanto juiz espectador. De acordo com Salo de Carvalho este modelo em que o juiz se coloca distante das partes e sem a iniciativa da ação penal, bem como da gestão das provas, opõe-se

officio, daí porque contaminaria o processo criminal onde o magistrado toma a figura de investigador de uma notícia criminal.

${ }^{7}$ Ingeborg Maus (2010) explica que o Judiciário foi elevado a uma posição de "instância moral superior da sociedade" (MAUS, 2010, p. 19). Para ela, isto traz consequências sérias à democracia, porque os conflitos se pautam em um domínio do direito "superior", através da subtração dos mecanismos de controle social.

${ }^{8}$ Essa expressão é utilizada por Alexandre Morais da Rosa ao se referir ao andamento do processo penal brasileiro, especialmente no aparelhamento do Estado voltado a persecução de crimes e a condenação dentro de decisões padrões que se dão em um rápido espaço de tempo, isto é, sem respeitar o devido tempo do processo legal na apuração de um crime. 
ao modelo inquisitório, "no qual o Juiz procede à busca e à valoração das provas, decidindo após procedimento instrutório escrito e sigiloso" (CARVALHO, 2010, p. 79).

O primado das hipóteses sobre os fatos nas lições do italiano Franco Cordero (1986) coloca o juiz-inquisidor em uma espécie de quadro mental paranoico que visa concentrar na primeira impressão das provas todo o seu convencimento, desprezando verdadeiras evidências diante de seu raciocínio lógico punitivo. $\mathrm{O}$ acusado é tratado como culpado desde o começo do "processo". Cabe ao juiz-inquisidor construir uma sequência dentro de sua hipótese paranoica.

Este é um quadro nocivo para democracia e para o sistema acusatório. O magistrado, para Coutinho (2001), deve revelar sua ideologia, e "é preciso que se saiba, para além dela (das regras), contra quem se está jogando e qual o conteúdo ético e axiológico do próprio jogo" (COUTINHO, 2001, p. 47). Isso só é possível quando os agentes que estão no palco do processo penal revelam sua face ideológica.

\section{A PUBLICIDADE DAS INTERCEPTAÇÕES E A VISIBILIDADE DO MAGISTRADO}

Existe uma fanpage na rede social Facebook denominada "Juiz Sérgio Moro, um herói Nacional". Atualmente conta com mais de 1 milhão de curtidas. Os administradores da página explicam que se trata apenas de uma homenagem ao juiz e que ela não tem nenhuma ligação direta com o magistrado, mas apenas a causa de defender um herói nacional. É interessante notar que, apesar da página deixar expressamente claro que não possui ligação com o magistrado, os debates que realiza, em grande maioria, visam criticar a política em geral, mas especificamente criticar o que concerne ao Partido dos Trabalhadores (PT) e ao governo Lula/Dilma.

Em outra página denominada apenas "Sérgio Moro" na plataforma social Facebook, os administradores colocaram como pauta apoiar e divulgar o incansável trabalho do juiz Sérgio Moro contra a corrupção. Deixaram claro ainda que nenhuma postagem dessa página corresponde ao pensamento do juiz Sérgio Moro. Da mesma forma que a supracitada, o que foi verificado são informações e ataques políticos aos partidos de esquerda, mas principalmente ao PT e seus agentes políticos. No dia 15 de fevereiro de 2016, foi colocado um trecho da palestra do magistrado em um evento sobre corrupção em que o respectivo afirma: 
Eu estou vinculado aos fatos, às provas e à Lei. E é isso que eu vou fazer nos meus processos, seja para absolver o inocente, seja para condenar o culpado. E eu me disponho a ir até o final nos meus casos. Mas esses casos envolvendo graves crimes de corrupção e figuras públicas poderosas, só podem ir adiante se contarem com o apoio da opinião pública e da sociedade civil organizada (FACEBOOK, 2016).

A popularidade do magistrado foi tamanha que o instituto Datafolha, em junho de 2017, realizou uma pesquisa sobre a eleição presidencial com índices de intenção de voto para o primeiro e segundo turno da eleição presidencial de 2018. No primeiro turno, Sérgio Moro (sem partido) empataria com Marina Silva com 14\% dos votos e Luiz Inácio Lula da Silva ficaria com $29 \%$ do eleitorado. No segundo, na projeção em que o ex-presidente disputasse com o magistrado, este ficaria com 44\% dos votos e Lula com 42\% (G1 GLOBO, 2017).

Em outra pesquisa política, novamente o nome de Moro se encontra inserido no jogo político, mas desta vez, o Datafolha mediu poder de influência na indicação de um candidato. Estavam na pesquisa Lula, Sérgio Moro, Fernando Henrique Cardoso (FHC) e Temer. Lula aparece com $29 \%$ de poder para indicar um candidato seguido de Sérgio Moro com 23\%. FHC aparece com 10\% e Michel Temer com o menor poder de indicação 3\% (G1 GLOBO, 2017b). Pesquisas políticas envolvem agentes políticos que estiveram durante muitos anos na trajetória de suas carreiras.

No clima de insatisfação e esquecimento do potencial de mudança através da política e dos políticos (WOLFF, 2007), a corrupção passou a fazer parte da primeira preocupação dos problemas a serem enfrentados, superando inclusive o cuidado com a saúde e a educação (FOLHA ONLINE, 2016). Há uma forte vinculação de um sentimento de descrença política especificamente ligada ao na época governo PT. O juiz é idolatrado porque se coloca numa posição de combatente da corrupção.

Edmilson Marques compara a dualidade existente entre o herói e o vilão. O primeiro só existe porque está presente uma ameaça:

\footnotetext{
As histórias dos super-heróis giram em torno da solução de um problema. Este problema está, na maioria das vezes, associado a um personagem que representa o mal [...]. O vilão é aquele que deve ser combatido pelo superherói por representar o mal. Diante da ameaça do mal é que entra em cena o grande e poderoso super-herói, o representante do bem. (MARQUES, 2011, p.114).
}

Mas aqui o que existe é um magistrado. É um agente público que exerce uma função técnica e mantém sua tarefa conforme os ditames constitucionais, não importando necessariamente quem ele é, sua imagem, seus hábitos privados, porque cumpre um papel que 
qualquer outro teria que desempenhar quando imbuído da função de julgador num cargo público.

As interceptações estão dentro do contexto das manifestações que, por sua vez, estão atravessadas pela Operação Lava Jato. $\mathrm{O}$ cidadão que foi às ruas ${ }^{9}$ queria uma mudança no cenário social e político, mas grande parte via apenas a mudança através do desejo de fazer justiça, principalmente com a esperança de que os agentes ligados ao PT fossem condenados e punidos pelo magistrado. É como se o sentimento de impunidade estivesse ligado aos agentes e, a partir de sua punição, o sujeito veria a Justiça se realizando através da prisão. A pessoa que está ligada a possibilidade de prender e punir "os poderosos" recebe todo reconhecimento simbólico.

Ele deixa então de ser fundamentalmente alguém que faz (ação) para ser alguém que representa um modelo otimizado dos valores que uma cultura entende como bons e próprios. O heroísmo converte-se assim em uma questão de percepção e consenso, em uma concretização da identidade coletiva. (TARDELI, 2011, p.131).

Por que um magistrado precisaria do apoio da opinião pública, por exemplo, se suas decisões são o dever de uma autoridade em propiciar conforme o Direito e o que dele provém na Constituição e na legislação? A opinião pública é uma causa externa e, muitas vezes, momentânea, podendo ser utilizada inclusive como estratégia política. Ela não se guia por valores jurídicos e não pode, assim, substituir o dever das cortes independentes de fazerem escolhas contramajoritárias.

No pedido de quebra de sigilo de dados telefônicos realizado pelo Ministério Público Federal (MPF) na investigação No 5006205-98.2016.4.04.7000/PR, o magistrado entendeu que não haveria mais necessidade de manter o sigilo, porque se fazia necessário propiciar a ampla defesa e a publicidade processual. Conforme o próprio despacho dado pelo Juiz:

[...] O levantamento propiciará assim não só o exercício da ampla defesa pelos investigados, mas também o saudável escrutínio público sobre a atuação da Administração Pública e da própria Justiça criminal. A democracia em uma sociedade livre exige que os governados saibam o que fazem os governantes, mesmo quando estes buscam agir protegidos pelas sombras (ESTADAO, 2016).

\footnotetext{
${ }^{9}$ A pluralidade de demandas nas manifestações mudou muito daquelas que se iniciaram com as chamadas jornadas de junho em 2013, encabeçadas pelo Movimento Passe Livre, até as que se passaram nos anos seguintes. O panorama inicial era o de indignação frente ao aumento da tarifa do transporte público na cidade de São Paulo. O Movimento Passe Livre organizou várias manifestações em algumas das principais cidades brasileiras. No entanto, ao decorrer dos protestos, diversos outros grupos estavam presentes e resistiam numa diversidade muito grande de demandas que no mais das vezes se traduziam em pautas conflitivas. A partir do ano de 2015, mais especificamente no mês de março, a principal bandeira que estava presente foi a de combate à corrupção.
} 
Segundo o magistrado, conforme tem decidido em casos semelhantes na Lava Jato, tratando de possíveis crimes contra a Administração Pública, o interesse público e a publicidade dos processos impedem o sigilo. Segundo ele, não há qualquer defesa da intimidade ou do interesse social que justifique, nos termos da Constituição, a manutenção do sigilo em relação a elementos probatórios da investigação de crimes contra a Administração pública (BRASIL, 2018). Ou seja, já se parte do pressuposto de que existiria aí, na conversa, uma pretensa caracterização de crime.

O princípio da publicidade foi gravado em três partes da Constituição Federal. Na primeira, conforme art. $5^{\circ}$ inc. LX, ele estabelece que a Lei só restringirá a publicidade a partir da defesa da intimidade ou do interesse social. A Lei Maior determina também, que a Administração Pública atuará conforme a publicidade, assim dispondo o art. 37. Por fim, a Constituição previu os julgamentos públicos, dispondo o art. 93, inc IX:

Todos os julgamentos dos órgãos do Poder Judiciário serão públicos, e fundamentadas todas as decisões, sob pena de nulidade, podendo a lei limitar a presença, em determinados atos, às próprias partes e a seus advogados, ou somente a estes, em casos nos quais a preservação do direito à intimidade do interessado no sigilo não prejudique o interesse público à informação (BRASIL, 1988).

Sobre a restrição à publicidade extensiva no processo, de forma análoga, o próprio art. 792 do Código de Processo Penal (CPP) §1º , restringe a publicidade para evitar escândalos, inconvenientes graves ou perigo de perturbação da ordem, quando da sessão da realização de julgamentos ou do ato processual. Outra limitação ao princípio da publicidade está especificada no art. 201, $\S 6^{\circ}$ do CPP o qual prevê a necessária preservação da intimidade, da vida privada, da honra e da imagem do ofendido, podendo o magistrado determinar o segredo de justiça em relação aos dados, depoimentos e outras informações constantes nos autos para evitar exposição aos meios de comunicação.

A importância da publicidade no processo penal é a de trazer o controle das partes sobre os atos do juiz, uma vez que delimita e impõe obrigações às autoridades para que se possa atuar no processo segundo o contraditório e a ampla defesa. Tanto a publicidade, quanto a comunicação e a cientificação dos atos processuais são essenciais dentro de um processo em que o magistrado seja um garantidor (LEITE, 2012). No entanto, tais balizas constitucionais se encontram efetivamente sentidas quando abusivamente expostas em mídia nacional, uma vez que há inegável prejuízo para o valor probatório do ato. É evidente que houve no caso em questão grande abalo a imagem, a intimidade e uma mudança drástica no campo político. 
Prevaleceu o prejuízo na exposição de grampos ilegais e não como coloca o magistrado, o contrário, a ampla defesa.

O argumento de que a divulgação proporcionaria o exercício do princípio supracitado não faz parte da realidade fática, porque este princípio se deve primordialmente a disponibilizar espaço processual e direito às partes poderem apresentar uma versão da história criminal. A cena foi inteiramente tomada por uma acusação do magistrado de obstrução da justiça, não levando em consideração as consequências globais da exposição.

\begin{abstract}
A democracia em uma sociedade livre exige que os governados saibam o que fazem os governantes, mesmo quando estes buscam agir protegidos pelas sombras. Isso é ainda mais relevante em um cenário de aparentes tentativas de obstrução à justiça, como reconhecido pelo Egrégio Supremo Tribunal Federal, ao decretar a prisão cautelar do Senador da República Delcídio do Amaral Gomez, do Partido dos Trabalhadores, e líder do Governo no Senado, quando buscava impedir que o exDiretor da Petrobrás Nestor Cuñat Cerveró, preso e condenado por este Juízo, colaborasse com a Justiça, especificamente com o Procurador Geral de Justiça e com o próprio Supremo Tribunal Federal (ESTADAO, 2016) (grifo nosso).
\end{abstract}

Dilma Rousseff não era investigada pela operação Lava Jato e não tinha qualquer envolvimento com crimes de corrupção ou lavagem de dinheiro. Ela exercia o cargo como $36^{\mathrm{a}}$ Presidenta do Brasil, primeira mulher a governar a chefia do Executivo na história do Estado brasileiro, durante seus 127 anos de Proclamação da República, em 15 de novembro de 1889 até 2016. Apesar de todas as críticas ao seu governo e ao modo de governar, não havia nenhum impedimento na nomeação de Luiz Inácio Lula da Silva para ocupar o cargo de Ministro Chefe da Casa Civil.

Luiz Inácio Lula da Silva era investigado pela Operação Lava Jato na fase Aletheia. Isso representa que havia uma apuração da prática de crime em curso realizada pela autoridade policial objetivando adquirir provas materiais ou formais que provassem ser ele o autor de fato criminoso. Em tese, para qualquer investigado, não existe uma acusação formal feita pelo Ministério Público, tampouco provas concretas que justifiquem qualquer tipo de prática de um ilícito penal. Existem informações que indicam a violação de tipo penal, mas nada concreto ${ }^{10}$.

O ex-presidente nesse momento ainda não estava nem indiciado pela Polícia Federal no tocante a Operação. Seu indiciamento se deu em 26 de agosto de 2016 (G1 GLOBO, 2016). Alexandre Morais da Rosa diferencia o indiciamento da mera suspeita de uma suposta prática criminal:

\footnotetext{
${ }^{10}$ De forma paralela, o ex-Presidente era investigado num esquema de fraudes, desvio de recursos e lavagem de dinheiro no âmbito da cooperativa Bancoop. Em 10.03.2016, foi ele denunciado pelo Ministério Público de São Paulo. Na peça, foi postulada a decretação da prisão preventiva. Em 14.3.2016, fundada na conexão com as investigações da Operação Lava Jato, a juíza da $4^{\mathrm{a}}$ Vara Criminal de São Paulo declinou da competência da respectiva ação penal para o Juízo responsável por aquela Operação, a 13 $3^{\mathrm{a}}$ Vara Federal de Curitiba.
} 
O indiciamento é ato formal pelo qual o sujeito passa a ocupar o lugar de indicado, isto é, a declaração pelo Estado de que há indicativos convergentes sobre sua responsabilidade penal, com os ônus daí decorrentes. A presunção de inocência veda o indiciamento arbitrário. Não pode ser considerado como mero ato automático. Pressupõe a apuração da materialidade da infração e informação suficiente de autoria. Diferencia-se o averiguado/suspeito do indiciado. Diante da legalidade, havendo indicativos, o indiciamento é obrigatório e traz como consequência o interrogatório, pregressamento, identificação criminal, acesso às informações já coletadas, via defesa técnica, dando-lhe um lugar na investigação preliminar (ROSA, 2013, p. 73)

A maneira como se colocou a imagem e os dados pessoais das conversas se traduziram em verdadeira prática criminal e grave acusação sobre os agentes. Registra-se, sem qualquer sentido de acusação. A nomeação do ex-presidente como ministro está nas possibilidades da Presidência da República conforme art. 84, inc. I da CF, já mencionado.

Um dia após a divulgação das interceptações, 17 de março de 2016, o magistrado profere um despacho em que afirma reconhecer um diálogo captado após a interrupção das gravações e juntado pela autoridade policial no evento 133. Há uma estranha negligência ao afirmar que "não havia reparado antes no ponto, mas não vejo maior relevância". A relevância foi capaz de intensificar manifestações em várias capitais do país, uma edição inteira do programa jornalístico assistido por mais de 10 milhões de pessoas (IBOPE, 2016) ${ }^{11}$, o andamento do processo de impeachment, etc.

Entre a decisão e a implementação da ordem junto às operadoras, colhido novo
diálogo telefônico, às 13:32h, juntado pela autoridade policial no evento 133. Não
havia reparado antes no ponto, mas não vejo maior relevância. Como havia justa causa
e autorização legal para a interceptação, não vislumbro maiores problemas no
ocorrido, valendo, portanto, o já consignado na decisão do evento 135. Não é ainda o
caso de exclusão do diálogo considerando o seu conteúdo relevante no contexto das
investigações, conforme já explicitado na decisão do evento 135 e na manifestação do
MPF do evento 132. A circunstância do diálogo ter por interlocutor autoridade com
foro privilegiado não altera o quadro, pois o interceptado era o investigado e não a
autoridade, sendo a comunicação interceptada fortuitamente (FAERMANN, 2016).

Não se trata apenas de respeitar a diferença do momento processual entre um investigado ou indiciado (no inquérito policial), um acusado (oferecimento da denúncia) e o réu (após recebimento da inicial acusatória pelo magistrado), mas refletir com o devido cuidado, as consequências que uma acusação criminal acarreta a partir do momento que são expostas em rede nacional.

\footnotetext{
${ }^{11}$ No ranking semanal, tomando as emissoras da TV aberta com programação monitorada pelo IBOPE, quais sejam, TV Band, Globo, Record, RedeTV! e SBT, entre os dias 14/03/2016 a 20/03/2016, exclusivamente no dia 16/03/2016, nos programas iniciados entre 20:00 e 22:30, o Jornal Nacional alcançou a $3^{\text {a }}$ posição com exatos 10.804,73 milhões de usuários.
} 
O magistrado argumenta que a comunicação foi interceptada fortuitamente, isto é, ocorreu por um mero acaso e que o foro privilegiado da Presidenta da República não altera o quadro, porque o investigado era o ex-presidente. Para Santos (2018) tal afirmativa abre um buraco na lei, permitindo que a intercepção seja feita no terminal telefônico de qualquer pessoa, uma vez que se invocaria o mero argumento de tomar a conversa fortuitamente e que o segredo de justiça poderia ser levantado para o investigado, mesmo este conversando com autoridade que detém foro por prerrogativa de função.

Justificar com base no contraditório depois que todos os atos judiciais foram para duas edições do Jornal Nacional exclusivamente sobre as interceptações telefônicas é, em um primeiro momento, ignorar todo o aparato do Judiciário para, por exemplo, realizar a ciência dos atos (citação, intimação ou notificação), utilizando o Diário Oficial ou dos serviços da própria Justiça, etc. Os áudios no Jornal Nacional não garantem oportunidade processual atentando ao princípio da isonomia, quiçá do contraditório judicial. Ainda que se argumente, fazendo uma interpretação literal do art. $5^{\circ}$, inc. LV, o qual dispõe "aos litigantes, em processo judicial ou administrativo, e aos acusados em geral são assegurados o contraditório e ampla defesa, com os meios e recursos a ela inerentes" (BRASIL, 1988), ao se falar em contraditório, se deve pensar fundamentalmente no elemento informação e na possibilidade da reação (CINTRA; GRINOVER; DINAMARCO, 2012, p. 63).

Mencionar o contraditório na fase pré-processual, ainda que amparado na posterior publicidade do processo, é um equívoco, pois não existe uma relação de igualdade no inquérito e, tampouco uma estrutura dialética de partes contrárias, realizando um exercício de pretensão resistida. Nessa fase, a polícia judiciária investiga e adota medidas que são preponderantemente restritivas de direitos fundamentais. O sigilo externo no âmbito inquisitório do inquérito deverá ser absoluto, isto é, sigiloso para população em geral. Assim o é, pois se argumenta melhorar as investigações, bem como proteger a imagem do investigado de uma possível e dura estigmatização social amparada por uma pretensa notícia de crime.

O sigilo ainda se torna importante, em razão de assegurar que medidas e diligências realizadas com a colocação prévia em qualquer meio de comunicação, tornaria inviável a colheita de elementos probatórios em geral, porque impediria o regular funcionamento do aparato investigatório policial. Ou seja, de fato não ocorreu um contraditório, ainda que diferido, pois não representou um efetivo direito à informação e paridade de armas (LOPES JR., 2016). Foi prolatada tal decisão sem dar oportunidade prévia de resposta e o caso ainda parece mais grave quando se verifica que não houve apreço sobre o sigilo, direito com 
fundamento constitucional, que diz respeito à Lei das interceptações telefônicas, Lei 9.296/96, a qual regulamenta o inciso XII, parte final, do art. $5^{\circ}$ da Constituição Federal.

O então Ministro Teori Zavascki em sua decisão liminar prolatada em 22 de março de 2016 já fazia referência à violação dos artigos $8^{\circ}$ e $9^{\circ}$ da supracitada Lei por parte do magistrado e, mesmo assim, o respectivo sequer mencionou a legislação em sua decisão. Nas palavras do Ministro: "o conteúdo das conversas - cujo sigilo, ao que consta, foi levantado incontinenti, sem nenhuma das cautelas exigidas em lei - passou por análise que evidentemente não competia ao juízo reclamado" (BRASIL, 2016b).

\section{CONSIDERAÇÕES FINAIS}

No modelo acusatório, o magistrado deve se pautar substancialmente pelo modelo democrático-acusatório, seguindo os princípios constitucionais, seja da imparcialidade, seja da independência. Nenhum juiz possui total neutralidade, todo indivíduo, inclusive um magistrado, possui certas predileções morais, religiosas e políticas que coadunam com sua visão de mundo, o modo como foi socializado no tempo e no espaço (ELIAS, 1994). No entanto, ao exercer a jurisdição, deve se colocar ainda que contramajoritário, em que pese existir forte consenso sobre determinados assuntos de grande repercussão.

O juiz não é nenhum herói, sequer um paladino que defende a Justiça de um bem maior. Essa posição não lhe diz respeito. O santo guerreiro não corresponde ao comportamento daquele que exerce função pública e deve grandemente seguir os preceitos previstos na Constituição Federal. A partir do momento que o magistrado toma uma postura de tornar públicas estas interceptações ilegais, ele se coloca em uma postura ativista punitiva.

Mesmo após a decisão que considerou ilegal as interceptações telefônicas, o Jornal Nacional que havia divulgado em duas edições exclusivas o teor das conversas, não realizou o mesmo procedimento para divulgar a ilicitude da exposição das conversas.

Os patamares penais foram elevados graças a um grande consenso conseguido, principalmente, através de batalhas com as grandes emergências do momento - corrupção política e o crime organizado - assim para cada dito mafioso colocado dentro do cárcere, mais cem dos jovens que se encontram em periferias também estarão presos. A cada político corrupto que se vê privado da liberdade e exposto na mídia, mais cem imigrantes trancafiados no cárcere (PAVARINI, 1996, p. 75). 
O magistrado em sua posição midiática de um ativismo punitivo edificou a posição de um grande defensor da moral pública contra a corrupção. Os bens simbólicos dessa posição legitimaram a deformação do campo político e a mancha na visibilidade dos agentes políticos ligados ao evento. O Judiciário serviu a mídia tal qual essa amplificou o fenômeno para o Judiciário. A ex-presidente Dilma Rousseff, transformada em corrupta sem qualquer relação com crime de corrupção, faz com que a saída de acordo com o populismo punitivo seja a prisão e punição. Cada nova criminalização é uma aproximação do perigo autoritário para toda população.

A pena para os agentes políticos já está dada e os respectivos já foram sentenciados a execração pública a partir da divulgação de tais conversas sem o devido cuidado com as provas de uma investigação criminal. A violação aos direitos e princípios constitucionais não são suficientes para frear a ânsia punitiva. Mesmo após serem consideradas ilegais a exposição de tais conversas, as consequentes estigmatizações jamais serão recuperadas.

\section{REFERÊNCIAS}

ALESSI, Gil. Foto de Moro e Aécio rindo juntos eletriza as redes em pleno caos no país. 2016. Disponível em:

$<$ https://brasil.elpais.com/brasil/2016/12/07/politica/1481121036_884537.html>. Acesso em 20 jul. 2018.

AMARAL, Augusto Jobim. ROSA, Alexandre Moraes da. Cultura da punição: a ostentação do horror. 2 ed. Florianópolis: Empório do Direito, 2015.

\section{BARATTA, Alessandro. Criminologia Crítica e Crítica do Direito Penal - Introdução a}

Sociologia do Direito Penal. Tradução Juarez Cirino dos Santos. 3ed. Rio de Janeiro: Revan; Instituto Carioca de Criminologia, 2002.

BRASIL. Constituição da República Federativa do Brasil de 1988. Diário Oficial da União, Brasília, DF, 5 out. 1988. Disponível em:

$<$ http://www.planalto.gov.br/ccivil_03/constituicao/constituicao.htm>. Acesso em: 7 jul. 2018. 
BRASIL. Departamento Penitenciário Nacional. Levantamento nacional de informações penitenciárias Infopen: junho de 2016. Brasília: Infopen, 2016a. Disponível em: $<$ http://depen.gov.br/DEPEN/noticias-1/noticias/infopen-levantamento-nacional-deinformacoes-penitenciarias-2016/relatorio_2016_22111.pdf>. Acesso em: 27 jan. 2018.

BRASIL, Supremo Tribunal Federal. Medida Cautelar na Reclamação 23.457. Min. Teori Zavascki. 2016b. Disponível em <https://www.conjur.com.br/dl/lava-jato-grampos-ilegaislula-dilma.pdf $>$ Acesso em 26 de ago. 2018.

BRASIL. Tribunal De Justiça do Paraná. Pedido de quebra de sigilo de dados e/ou telefônica n. 5006205-98.2016.4.04.7000/PR. Requerente: Ministério Público Federal. Disponível em: $<$ https://www.conjur.com.br/dl/decisao-levantamento-sigilo.pdf $>$. Acesso em 19 jul. 2018.

CANOTILHO, José Joaquim Gomes. Estado de Direito. Lisboa: Gradiva, 1999. Disponível em: http://www.buscalegis.ufsc.br/revistas/files/anexos/32571-39731-1-PB.pdf. Acesso em 12 de jan. 2018.

CARVALHO, Salo de. O papel dos atores do sistema penal na era do punitivismo. Rio de Janeiro: Lúmen Juris, 2010.

CINTRA, Antônio Carlos de Araújo. DINAMARCO, Cândido Rangel. GRINOVER, Ada Pellegrini. Teoria geral do processo. Malheiros, 2012.

CHAUI, Marilena. Manifestações ideológicas do autoritarismo brasileiro. Belo Horizonte: Autêntica Editora. Editora Fundação Perseu Abramo, 2013.

CORDERO, Franco. Guida alla Procedura Penale. Torino: Utet, 1986.

COUTINHO, Jacinto Nelson de Miranda. Crítica à teoria geral do direito processual penal. Rio de Janeiro: Renovar, 2001.

ELIAS, Norbert. A sociedade dos indivíduos. Rio de Janeiro: Jorge Zahar Ed. 1994. 
ESTADAO. Moro quebra sigilo telefônico de ex-presidente. 2016. Disponível em: $<$ http://politica.estadao.com.br/blogs/fausto-macedo/wpcontent/uploads/sites/41/2016/03/Evento-135-DESPADEC11.pdf>. Acesso em: 31 mai. 2017.

FAERMANN, Patricia. MPF admite o comando da Lava Jato e Moro inspira-se em Watergate. 2016. Disponível em: <http://jornalggn.com.br/noticia/mpf-admite-o-comandoda-lava-jato-e-moro-inspira-se-em-watergate>. Acesso em: 31 maio 2017.

FACEBOOK. Sérgio Moro vinculado aos fatos, às provas e à Lei. 2016. Disponí1vel em: $<$ https://www.facebook.com/SFM.SÉRGIOMORO/videos/1697857890471379/>. Acesso em 11 de jul. 2018.

FOLHA ONLINE. Saúde supera corrupção como pior problema para a população. 2016. Disponível em: < https://www1.folha.uol.com.br/poder/2016/12/1840371-saude-superacorrupcao-como-pior-problema-para-a-populacao.shtml>. Acesso em 07 de jun. 2018.

G1 GLOBO. Lula tem 30\%, Bolsonaro, 16\%, e Marina, 15\%, aponta pesquisa Datafolha para 2018. 2017a. Disponível em: <https://g1.globo.com/politica/noticia/lula-tem-30bolsonaro-16-e-marina-15-aponta-pesquisa-datafolha-para-2018.ghtml $>$. Acesso em 11 de ago. 2018.

. Datafolha aponta que 29\% votariam em candidato indicado por Lula. 2017b.

Disponível em: <https://g1.globo.com/politica/noticia/datafolha-aponta-que-29-votariam-emcandidato-indicado-por-lula.ghtml>. Acesso em 11 de ago. 2018.

PF indicia ex-presidente Lula, Marisa e mais três em processo da Lava Jato. 2016. Disponível em: <http://g1.globo.com/pr/parana/noticia/2016/08/pf-indicia-expresidente-lula-marisa-e-mais-tres-em-processo-da-lava-jato.html>. Acesso em 23 ago. 2018.

IBOPE. Instituto Brasileiro de Opinião Pública e Estatística. Ranking Semanal - 15 Mercado - 14/03/2016 a 20/03/2016. Disponível em:

$<$ https://www.kantaribopemedia.com/ranking-semanal-15-mercado-14032016-a-20032016/> Acesso em: 12 de jul. de 2018. 
LEITE, L.. O conteúdo da publicidade no processo penal brasileiro: uma análise da jurisprudência dos tribunais superiores. In: XXI Congresso Nacional do CONPEDI, 2012, Niterói. O Novo Constitucionalism Latino Ame ricano: desafios da sustentabilidade Processo e jurisdição. Florianopolis: FUNJAB, 2012. p. 06-532.

LOPES JR., Aury. Direito processual penal. 13ª ed. - São Paulo: Saraiva, 2016.

MARQUES, Edmilson. Super-Heróis: ficção e realidade. In: VIANA, Nildo; REBLIN, Iuri Andréas (Org.). Super-heróis, cultura e sociedade: aproximações multidisciplinares sobre o mundo dos quadrinhos. Aparecida: Ideias \& Letras, 2011.

MAUS, Ingeborg. O judiciário como superego da sociedade. trad. de Geraldo de Carvalho e Garcélia Batista de Oliveira Mendes. Rio de Janeiro, Lumen Juris, 2010.

MINISTÉRIO PÚBLICO FEDERAL. Combate à corrupção: caso lava jato. Disponível em $<$ http://www.lavajato.mpf.mp.br/>. Acesso em: 16 de jul. de 2018.

OITOMEIA. Movimento Vem Pra Rua expõe "Pixuleco" e "Super Moro" durante visita de Lula. 2017. Disponível em:

$<$ https://www.oitomeia.com.br/noticias/2017/09/03/movimento-vem-pra-rua-expoe-pixulecoe-super-moro-durante-visita-de-lula>. Acesso em 23 ago. 2018.

PAVARINI, Massimo. O instrutivo caso italiano. Revista Discursos Sediciosos: crime, direito e sociedade, $\mathrm{n}^{\circ}$ 2. Rio de Janeiro: ICC, 1996.

ROSA, Alexandre Morais da. Guia compacto do processo penal conforme a teoria dos jogos. Rio de Janeiro: Lumen Juris, 2013.

SANTOS, Juarez Cirino dos. O escândalo do levantamento do sigilo das interceptações telefônicas. 2018. Disponível em: <http://justificando.cartacapital.com.br/2018/01/15/oescandalo-do-levantamento-do-sigilo-das-interceptacoes-telefonicas/>. Acesso em: 25 ago. 2018. 
TARDELI, Denise D`Aurea. Super-heróis na construção da personalidade. In: VIANA, Nildo; REBLIN, Iuri Andréas (Org.). Super-heróis, cultura e sociedade: aproximações multidisciplinares sobre o mundo dos quadrinhos. Aparecida: Ideias \& Letras, 2011.

THOMPSON, John B. EI escándalo político. Poder y visibilidad en la era de los medios de comunicación, Barcelona, Paidós Ibérica, 2001.

WOLFF, Francis. Esquecimento da Política ou Desejo de Outras Políticas? In: O

Esquecimento da Política, Adauto Novaes (org.), Rio de Janeiro: Agir, 2007.

ZAFFARONI, Eugênio Raúl. O inimigo no Direito Penal. Tradução de Sérgio Lamarão. Rio de Janeiro: Revan, 2007.

A Questão Criminal. Tradução Sérgio Lamarão - 1ed. Rio de Janeiro: Revan, 2013.

ZAFFARONI, Eugenio Raúl; PIERANGELLI, José Henrique. Manual de Direito Penal Brasileiro - Parte Geral vol. 1. 9 ed. rev. e atual. São Paulo: Ed. Revista dos Tribunais, 2011.

THE CONSEQUENCES OF THE PERFORMANCE OF THE MAGISTRATE SÉRGIO MORO IN THE CASE OF THE DISCLOSURE OF TELEPHONE INTERCEPTIONS IN MARCH 2016

\begin{abstract}
This paper aims to demonstrate the problematic and consequences of the visibility given by a magistrate taking as a case study the disclosure of telephone interceptions in two editions of the National Journal in March 2016. Faced with a profession that demands impartiality, dedication, prudence, speed and discernment, what are the political and juridical consequences of the one who is in the position of judge and for the parts of the decisions pronounced by that agent, the analysis will be developed from an investigation involving Luiz Inácio Lula da Silva and that affects the figure of former president Dilma Rousseff. We work with theoretical-bibliographic research, using the theoretical framework provided by sociology and criminology. The performance
\end{abstract}


| Revista Transgressões: ciências criminais em debate, v. 7, junho de 2019

of the magistrate violated constitutional rights and principles, causing a great stain on the image of the politicians involved.

Keywords: Judiciary. Magistrate. Telephone interceptions. Punitivism. 